\title{
EVALUASI JARINGAN PIPA DISTRIBUSI AIR BERSIH DISTRIK AIMAS KABUPATEN SORONG
}

\author{
Perwira Budiman Sarluf \\ Program Studi Teknik Sipil Universitas Muhammadiyah Sorong \\ Jalan Pendidikan No. 27 Kota Sorong Provinsi Papua Barat \\ Email : perwirabudiman1@gmail.com
}

\begin{abstract}
ABSTRAK
Kabupaten Sorong terdiri dari beberapa Distrik salah satunya adalah Distrik Aimas yang sekaligus menjadi Ibu Kotanya. Perkembangan Distrik Aimas dapat di lihat dari adanya Perusahaan yang mengelola jaringan pipa air bersih yang selama ini memenuhi kebutuhan air bersih di setiap kelurahan -kelurahan di Distrik Aimas. Tujuan dari penelitian ini yaitu mengevaluasi kinerja pelayanan penyedia air bersih selama ini dengan pertumbuhan penduduk yang terus meningkat setiap tahun. Metode yang digunakan pada penelitian ini dengan melakukan observasi secara langsung pada daerah-daerah pelayanan air bersih dan di analisa menggunakan Sofware Epanet 2.0.
\end{abstract}

Kata Kunci : Distrik Aimas, Kinerja Pelayanan, Epanet 2.0.

\section{PENDAHULUAN}

\section{Latar Belakang}

Kabupaten Sorong terletak pada wilayah bagian timur Indonesia pulau Papua Barat. Secara umum kondisi masyarakat Kabupaten Sorong khususnya Distrik Aimas bersifat heterogen yaitu terdiri dari pegawai, wiraswasta,dan mayoritas sebagai petani. Perkembangan yang terus terjadi pada daerah ini salah satunya dapat dilihat dengan adanya penyedia air bersih akan tetapi terus dengan bertambahnya jumlah penduduk dan meningkatnya pemakai air bersih menyebabkan pelayanan penyedia air bersih menurun dari aspek kuantitas dan kontinuitas akibat fluktuasi.

\section{Tujuan Penelitian}

Adapun tujuan dari penelitian ini untuk mengetahui kinerja pelayanan pada penyedia air bersih yang ada pada wilayah Distrik Aimas Kabupaten Sorong.

\section{STATE OF THE ART}

Adapun beberapa penelitian terdahulu yang berkaitan dengan penelitian ini adalah sebagai berikut :

1. Searphin Nugroho, Ika Meicahayanti, Juli Nurdiana (2018) Kajian Tentang Analisa Jaringan Perpipaan Distribusi Air Bersih Menggunakan Epanet 2.0. Penelitian dilakukan 
pada Kelurahan Harapan Baru, Kota Samarinda. Dari hasil penelitian diketahui ada 7 junction yang nilai tekanan airnya berada dibawah batas minimum kriteria pipa distribusi dari PP PU No. 18/PRT/M/2007 sebesar 0,5 atm, serta banyak 11 pipa yang nilai kecepatan aliran airnya dibawah batas minimum kriteria yang sebesar $0,3 \mathrm{~m} / \mathrm{s}$ barometer pelanggan dan kontinuitas, yaitu perubahan tekanan pada valve exsisting, dan penambahan pompa booster di beberapa titik. Dan terdapat perbedaan signifikan antara simulasi Epanet 2.0 dan pengukuran langsung pada kran pelanggan.

2. Agustina Hotmarito Napitu (2019) Kajian Tentang Evaluasi Jaringan Pipa Distribusi Air Bersih PDAM Tirtanadi Cabang Toba Samosir Unit Porsea Menggunakan Aplikasi Epanet 2.0. Penelitian ini Kecamatan Porsea Sumatra Utara. Metode yang digunakan dengan menganalisa menggunakan Aplikasi Epanet 2.0, berdasarkan hasil perhitungan didapat rata-rata pemakaian pelanggan perbulan di PDAM Tirtanadi Cabang Toba Samosir unit Porsea adalah 118 liter/orang/hari dengan persentase kehilangan air sebesar 32,5\% yaitu 57 liter/orang/hari. Kapasitas kebutuhan air di unit Porsea adalah 788.000 liter/hari. Kebutuhan air pada saat jam puncak pada unit Porsea di masing - masing wilayah adalah 105.875 liter/hari untuk wilayah I, 162.750 di wilayah II, sebesar 757.750 liter/hari pada wilayah III, dan 352.625 liter/hari untuk wilayah IV. Pipa distribusi PDAM Tirtanadi Cabang Toba Samosir unit Porsea menggunakan jenis pipa HPDE dengan diameter 2 inchi $(50 \mathrm{~mm}), 3$ inchi $(75 \mathrm{~mm}), 4$ inchi $(10 \mathrm{~mm}), 6$ inchi $(150 \mathrm{~mm})$. Hasil penelitian ini menyimpulkan bahwa sistem distribusi air bersih di PDAM Tirtanadi cabang Toba Samosir unit Porsea kurang bak, dimana sistem distribusi air bersih belum dapat melayani pelanggan unit Porsea secara menyeluruh.

3. Titiek Ujianti Karunia (2013) Kajian Tentang Analisa Sistem Distribusi Air Bersih Di Perumahan Taman Yasmin Sektor Enam Bogor Jawa Barat. Penelitian bertujuan untuk menganalisa sistem distribusi air bersih di Perumahan Taman Yasmin Sektor Enam, dengan analisis berdasarkan hasil kuesioner dan EPANET 2.0. Berdasarkan hasil wawancara dengan 40 responden menyatakan bahwa air yang diterima layak, Demikian pula dengan uji kualitas diketahui bahwa air bersih yang disalurkan sesuai dengan baku mutu PERMENKES No.492/MENKES/Per/IV//2010. Debit air yang masuk ke inlet sebesar 7.05 1/dt sehingga total kebutuhan air 2.67 1/dt dapat terpenuhi. Pada simulasi dengan program EPANET 2.0 terdapat 4 node yang tekanannya lebih dari 2 bar pada pipa tersier untuk itu dibutuhkan pemasangan PRV untuk mengurangi tekanan pada ke empat node tersebut karena pada pipa tersier maksimum tekanan 2 bar.

4. Andry Sudirman (2012) Kajian Tentang Analisa Pipa Jarinfan Distribusi Air Bersih Di Kabupaten Maros Dengan Menggunakan Sofware Epanet 2.0. Tujuan penelitian ini adalah untuk mengetahui apakah perlu penambahan produksi air untuk memenuhi kebutuhan air bersih pelanggan PDAM Maros saat ini, melakukan simulasi jaringan pipa distribusi air bersih di Kabupaten Maros dengan menggunakan software EPANET 2.0, dan membandingkan hasil simulasi jaringan pipa distribusi air bersih dengan menggunakan software EPANET 2.0 dengan hasil perencanaan sistem jaringan pipa 
distribusi kondisi eksisting saat ini. Dari hasil perhitungan diperoleh kebutuhan rata-rata harian sebesar 116,926 liter/detik masih dibawah produksi air IPA Bantimurung dan Patontongan sebesar 130 liter/detik. Berdasarkan hasil simulasi diperoleh nilai tekanan untuk jam puncak pemakaian air yaitu pada pukul 06.00 WITA sebesar 68,3 m untuk tekanan tertinggi sedangkan tekanan terendah sebesar 1,08 $\mathrm{m}$. Selain itu dilakukan pula perbandingan nilai tekanan hasil simulasi dengan hasil pengukuran lapangan di Perumahan Tumalia. Dari perbandingan tersebut diperoleh nilai tekanan hasil simulasi sebesar 6,06 m sedangkan nilai tekanan pengukuran lapangan yang dilakukan oleh tim NRW PDAM Maros di perumahan ini sebesar 6,11 m. Adanya perbedaan nilai tekanan disebabkan oleh faktor umur pipa, kebocoran air, dan data penelitian yang terbatas.

5. Hendra Hafid Fathony (2012) Kajian Tentang Analisis Sistem Distribusi Air Bersih PDAM Karanganyar. Penelitian ini dilakukan di Karaganyar tepatnya pada PDAM Karanganyar. Penelitian ini adalah deskriptif kuantitatif untuk megetahui jumlah kebutuhan air pelanggan PDAM Karanganyar untuk lingkup Karanganyar, Jaten, dan Perumahan Palur. Dari hasil analisis dengan menggunakan realisasi kebutuhan diperoleh kebutuhan air bersih pelanggan PDAM Karanganyar untuk tahun 2016 sebesar 157.58 1/dt. Perkiraan debit air bersih yang dibutuhkan untuk tahun 2016 pada Kecamatan Karanganyar sebesar $Q=109.33$ l/dt, Perumnas Palur $Q=39.18 \mathrm{l} / \mathrm{dt}$, dan Jaten $\mathrm{Q}=40.59$ 1/dt. Besarnya volume penambahan pelanggan untuk tahun 2016 wilayah Karanganyar, Jaten, Perumnas Palur adalah sebesar $0.0125 \mathrm{~m}^{3} / \mathrm{dt}$. Dengan jumlah debit tersebut kemungkinan dapat ditambah jumlah pelanggan PDAM Karanganyar sebesar 2.913 pelanggan. Analisis kapasitas pipa pada lima tahun mendatang 2016 untuk daerah perumnas Palur dimensi pipa masih mampu mengalirkan air dari reservoir Popongan kecuali pipa nomor satu yang perlu pembesaran pipa.

\section{METODE}

\section{Tahapan Penelitian}

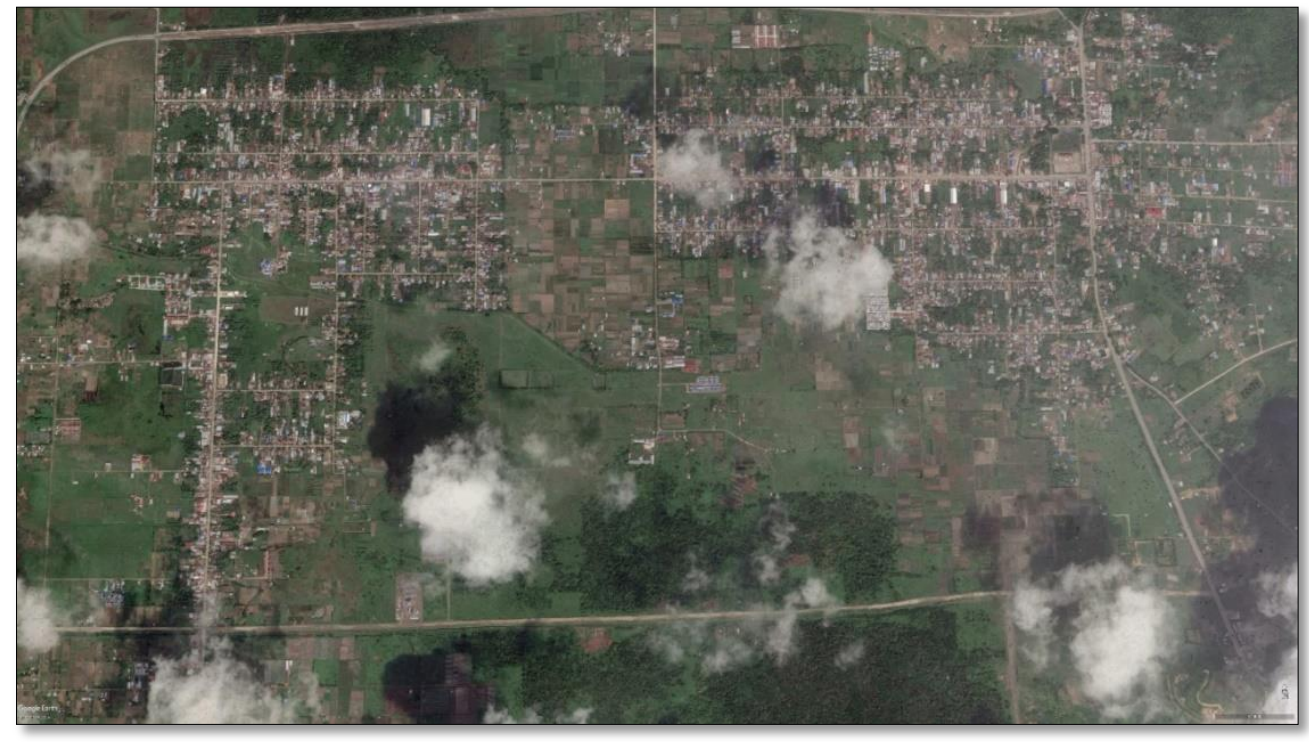


Adapun tahapan penelitian yang digunakan adaah sebagai berikut :

1. Melakukan studi pustaka dari beberapa buku - buku, jurnal, skripsi terkait dengan judul penelitian yang diteliti.

2. Mempersiapkan alat bantu seperti : GPS, alat tulis, kamera dan peralatan penunjang lainnya.

3. Melakukan observasi lapangan dan wawancara pada instansi terkait untuk mengumpulkan data dan informasi.

4. Menggunakan program bantu Epanet 2.0 untuk menganalisa data yang telah di peroleh.

Semua meteode penulisan dan analisa dalam artikel ilmiah ini merujuk pada panduan penulisan tugas akhir Fakultas Teknik Universitas Muhammadiyah Sorong Tahun 2014 (Pristianto, Amri, \& Rusdi, 2014).

\section{REFERENSI}

1. Nugroho, S., Meicahayanti, I., \& Nurdiana, J. Analisis Jaringan Perpipaan Distribusi Air Bersih Menggunakan EPANET 2.0 (Studi Kasus di Kelurahan Harapan Baru, Kota Samarinda). TEKNIK, 39(1).

2. Napitu, A. H. (2018). Evaluasi Jaringan Pipa Distribusi Air Bersih PDAM Tirtanadi Cabang Toba Samosir Unit Porsea Menggunakan Aplikasi EPANET 2.0.

3. Titiek Ujianti Karunia, 2013, Analisis Sistem Distribusi Air Bersih Di Perumahan Taman Yasmin Sektor Enam Bogor Jawa Barat, Bogor, Institut Pertanian Bogor.

4. Sudirman, A. Analisa Pipa Jaringan Distribusi Air Bersih Di Kabupaten Maros Dengan Menggunakan Software Epanet 2.0.

5. Hendra Hafid Fathony, 2012, Analisis Sistem Distribusi Air Bersih PDAM Karanganyar, Universitas Sebelas Maret, Surakarta.

6. Rossman, Lewis A. 2000. User Manual Epanet 2.0 Versi Bahasa Indonesia. Ekamitra Engineering, Penerjemah. Ohaio (US): Ekamitra Engeering.

7. DPU Ditjen Cipta Karya, (2007). Pedoman Kebijakan Program Pembangunan Prasarana Kota Terpadu (P3KT). Jakarta : Depertemen Pekerjaaan Umum, Direktorat Jenderal Cipta Karya.

8. Peraturan Menteri Pekerjaan Umum (2007). Penyelenggaraan Pengembangan Sistem Penyedia Air Minum. Jakarta : Menteri Pekerjaan Umum Republik Indonesia.

9. [DPU DCK] Depertemen Pekerjaan Umum Dirjen Cipta Karya. 2000. Konsumsi Air Berdasarkan Kategori Kota. Depertemen Pekerjaan Umum Dirjen Cipta Karya.

10. Permenkes No. 492 (2010). Persyaratan Kualitas Air Minum. Jakarta : Menteri Kesehatan Republik Indonesia.

11. Triadmodjo, Bambang, 1996, Hidraulika II, Beta Offset, Yogyakarta 